\section{Scorpion bite, a sting to the heart!}

Sir,

We read the article "Scorpion bite, a sting to heart" by Agrawal et al. ${ }^{[1]}$ with great interest. The author reported a case of 14-year-old male patient with scorpion bite on the right toe. We want to highlight certain issues regarding diagnosis and management of this patient.

Cardiotoxic effects due to scorpion bite are not rare complications as demonstrated by Kumar et al. that almost more than one-third of these patients have one or more cardiovascular effects. ${ }^{[2]}$ Prazosin and anti-scorpion venom (SAV) should be the primary line of treatment, as alpha receptors stimulation by the toxin results in hypertension, tachycardia, myocardial dysfunction, pulmonary edema, and cool extremities. ${ }^{[3]}$ However, it has been seen that the late administration of SAV may be effective as the antivenom creates a concentration gradient between plasma and target tissue. The venom bound to antivenom gets excreted, and the toxin in the tissues moves down the concentration gradient into the blood and gets bound by the antivenom. Therefore, even if the venom is not immediately neutralized by antibodies, its removal from the tissue may cause relief in symptoms. ${ }^{[3]}$

Electrocardiography (ECG) is the most important and easily available tool. No victim with systemic involvement shows normal ECG. RST segment and T waves are most frequently affected. Early myocardial infarction-like pattern, atrial arrhythmias, nonsustained ventricular tachycardia and varied conduction defect due to injury to the conducting system are seen. Conduction defect restore to normal within 1 week, T wave inversion persist for a few weeks. At times, despite good clinical status of the victim, ECG showed mark abnormalities. ${ }^{[4]}$
Echocardiography is a useful tool for evaluating the various parameters of cardiac function. Echo shows poor global myocardial contractility within 12-15 h of sting, with low ejection fraction, decreased left ventricular performance, and abnormal diastolic filling for 5 days to 4 weeks. Diminished or hypokinetic left ventricular global movement with decrease systolic function was seen in the scintigraphic study. There is a good correlation between clinical improvement and return to normal left ventricular function. ${ }^{[5]}$

Karnad from India studied haemodynamic pattern in eight scorpion sting cases of Mesobuthus tamulus sting. He recorded severe vasoconstriction and hypertension in mild envenoming while predominant left ventricular dysfunction with normal systemic vascular resistance causing pulmonary edema or severe hypotension in severe envenomation. ${ }^{[6]}$ These patients are benefitted by the early use of inotropes and vasodilators, which reduce the afterload on the heart. These physiologic principles make dobutamine and milrinone as vasoactive drugs of choice instead of Noradrenaline as used by authors in the index case.

Amiodarone a neuromodulator improves the survival by reduction of serum nor-epinephrine level in four children with scorpion sting who had severe left ventricular dysfunction with raised troponin and serum norepinephrine. ${ }^{[7]}$

Early hospitalization after sting, and administration of SAV are the key factors in reducing the myocardial dysfunction, and hence related morbidity and mortality.

\section{Financial support and sponsorship} Nil.

\section{Conflicts of interest}

There are no conflicts of interest. 
Gajanan Yelme, Atul Jindal

Department of Pediatrics, All India Institute of Medical Sciences, Raipur, Chhattisgarh, India

Correspondence: Dr. Atul Jindal,

Department of Pediatrics, All India Institute of Medical Sciences, Raipur - 492 099, Chhattisgarh, India. E-mail: dratuljindal@gmail.com

\section{References}

1. Agrawal A, Kumar A, Consul S, Yadav A. Scorpion bite, a sting to the heart! Indian J Crit Care Med 2015;19:233-6.

2. Kumar PM, Krishnamurthy S, Srinivasaraghavan R, Mahadevan S, Harichandrakumar KT. Predictors of myocardial dysfunction in children with Indian red scorpion (Mesobuthus tamulus) sting envenomation. Indian Pediatr 2015;52:297-301.

3. Pandi K, Krishnamurthy S, Srinivasaraghavan R, Mahadevan S. Efficacy of scorpion antivenom plus prazosin versus prazosin alone for Mesobuthus tamulus scorpion sting envenomation in children: A randomised controlled trial. Arch Dis Child 2014;99:575-80.

4. Bawaskar HS, Bawaskar PH. Cardiovascular manifestations of severe seorpion sting in India (review of 34 children). Ann Trop Paediatr 1991;11:381-7.

5. Kumar EB, Soomro RS, al Hamdani A, el Shimy N. Scorpion venom cardiomyopathy. Am Heart J 1992;123:725-9.

6. Karnad DR. Haemodynamic patterns in patients with scorpion envenomation. Heart 1998;79:485-9.

7. Santiago JJ, Dávila CA, Davila DF, Donis JH, Villaroel V. Antiadrenergic rescue therapy with amiodarone in children with severe left ventricular dysfunction secondary to scorpion envenomation. Arq Bras Cardiol 2010;94:18-23.

This is an open access article distributed under the terms of the Creative Commons Attribution-NonCommercial-ShareAlike 3.0 License, which allows others to remix, tweak, and build upon the work non-commercially, as long as the author is credited and the new creations are licensed under the identical terms.

\begin{tabular}{|l|l|}
\hline \multicolumn{2}{|c|}{ Access this article online } \\
\hline Quick Response Code: & Website: \\
\hline & www.ijccm.org \\
\cline { 2 - 3 } & Dol: 10.4103/0972-5229.182198 \\
\hline
\end{tabular}

How to cite this article: Yelme G, Jindal A. Scorpion bite, a sting to the heart!. Indian J Crit Care Med 2016;20:309-10. 